\title{
Systematic Fractionation of Sarcoplasmic Proteins of Rat Skeletal Muscle
}

\author{
By Tadashi NoguchI and Makoto Kandatsu \\ Department of Agricultural Chemistry, Faculty of Agriculture, \\ The University of Tokyo, Bunkyo-ku, Tokyo \\ Received September 29, 1971
}

Fractionation of sarcoplasmic proteins of various species has long been tried mainly by two groups of authors. One group has an interest in the metabolism of sarcoplasmic proteins $^{1-12,14}$ and the other in the postmortem changes of muscle. ${ }^{13,19-21,23,24)}$ Several techniques of protein fractionation have been applied; ammonium sulfate, ${ }^{2,51}$ acetone, ${ }^{71}$ free boundary electrophoresis, ${ }^{3,4,6 !}$ chromatography on ion exchange celluloses ${ }^{10,14,15,20,21,231}$ and starch, ${ }^{9,11 \sim 14,16,18,19,22,24)}$ acrylamide or agar gel electrophoresis. Especially, by using ion exchange celluloses or gel electrophoresis, more than 10 components have been identified as the components of sarcoplasmic proteins.

However, systematic fractionation of sarcoplasmic proteins by combination of several techniques seems not to have been fully attempted. In the present investigation, systematic fractionation of sarcoplasmic proteins of rat skeletal muscle by applying ammonium sulfate fractionation, CM-cellulose and DEAEcellulose chromatography has been attempted. The fractions obtained were identified and their purity was checked by means of starch gel electrophoresis.

Animals. Adult male Wistar strain albino rats were used throughout the experiments. Animals were fed on the stock diet of this laboratory ${ }^{251}$ containing $76 \%$ wheat, $15 \%$ fish meal, $5 \%$ alfalfa meal, $2 \%$ soybean oil, $1 \%$ dried brewer's yeast, $0.7 \%$ calcium carbonate, and $0.3 \%$ sodium chloride.
Preparation of sarcoplasmic proteins. Sarcoplasmic proteins were prepared according to Hartshorne and Perry, ${ }^{14}$ as follows: Rats were lightly anesthetized with ether and slaughtered by exanguination. Hind limbs were quickly excised and chilled in ice cold homogenizing solution $(20 \mathrm{mM}$ tris- $50 \mathrm{mM} \mathrm{KCl}-$ $\mathrm{HCl}, \mathrm{pH}$ 7.6). Thereafter, the limbs were blotted and muscles were separated from bones. Large connective tissues and fat pads were removed. Muscles were cut into small pieces by a pair of scissors and homogenized in a Waring blendor-type homogenizer with a volume of the homogenizing solution 3 times their weight. The homogenate was centrifuged for $20 \mathrm{~min}$ at $10,000 \times \mathrm{g}$ and the supernatant was used as the sample proteins.

Ammonium sulfate fractionation. Solid ammonium sulfate was added to the sarcoplasm until the saturation level indicated in the figure was attained, keeping $\mathrm{pH}$ of the solution from 6.0 to 6.3 by adding solid $\mathrm{Na}_{2} \mathrm{HPO}_{4}$. The precipitate was centrifuged and dissolved in $40 \mathrm{~mm}$ glycine- $\mathrm{NaOH}(\mathrm{pH} 9.1$ ) buffer.

Column chromatography on ion exchange cellulose. CM-cellulose and DEAE-cellulose were treated on a filter alternately with $0.5 \mathrm{~N} \mathrm{HCl}$ and $0.5 \mathrm{~N} \mathrm{NaOH}$, and they were washed with distilled water between and after each treatment until the washings reached near neutral range. DEAE-cellulose was first treated with acid and then alkali, whereas the reverse 


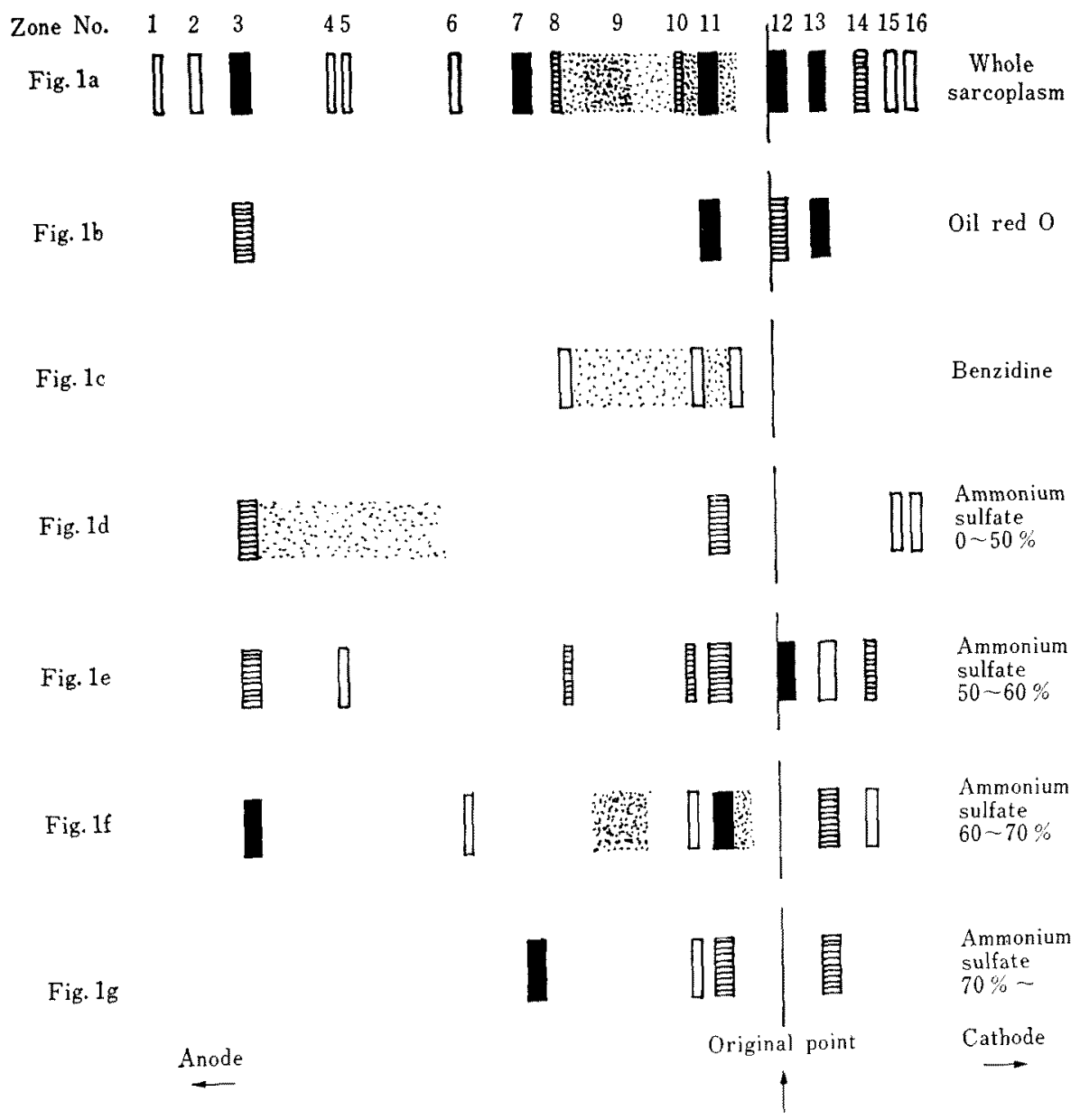

FIG. 1. Starch Gel Electrophoresis of Sarcoplasm of Rat Skeletal Muscle.

1 a: Whole sarcoplasm stained by Amido Black $10 \mathrm{~B}$.

1 b: Whole sarcoplasm stained by Oil Red $O$.

$1 \mathrm{c}$ : Whole sarcoplasm stained by benzidine.

$1 \mathrm{~d}$ : Sarcoplasmic proteins precipitated at $0 \sim 500^{\circ}$ saturation of $\left(\mathrm{NH}_{4}\right)_{2} \mathrm{SO}_{4}$.

le: Sarcoplasmic proteins precipitated at $50 \sim 60 \%$ saturation of $\left(\mathrm{NH}_{4}\right)_{2} \mathrm{SO}_{4}$.

If: Sarcoplasmic proteins precipitated at $60 \sim 70 \%$ saturation of $\left(\mathrm{NH}_{4}\right)_{2} \mathrm{SO}_{4}$.

$\mathrm{lg}$ : Sarcoplasmic proteins soluble at $70^{\circ}$ saturation of $\left(\mathrm{NH}_{4}\right)_{2} \mathrm{SO}_{4}$.

Strongly stained zones

冒 Weakly stained zones

$\square$ Faintly stained zones

Stained parts not showing clear zones 


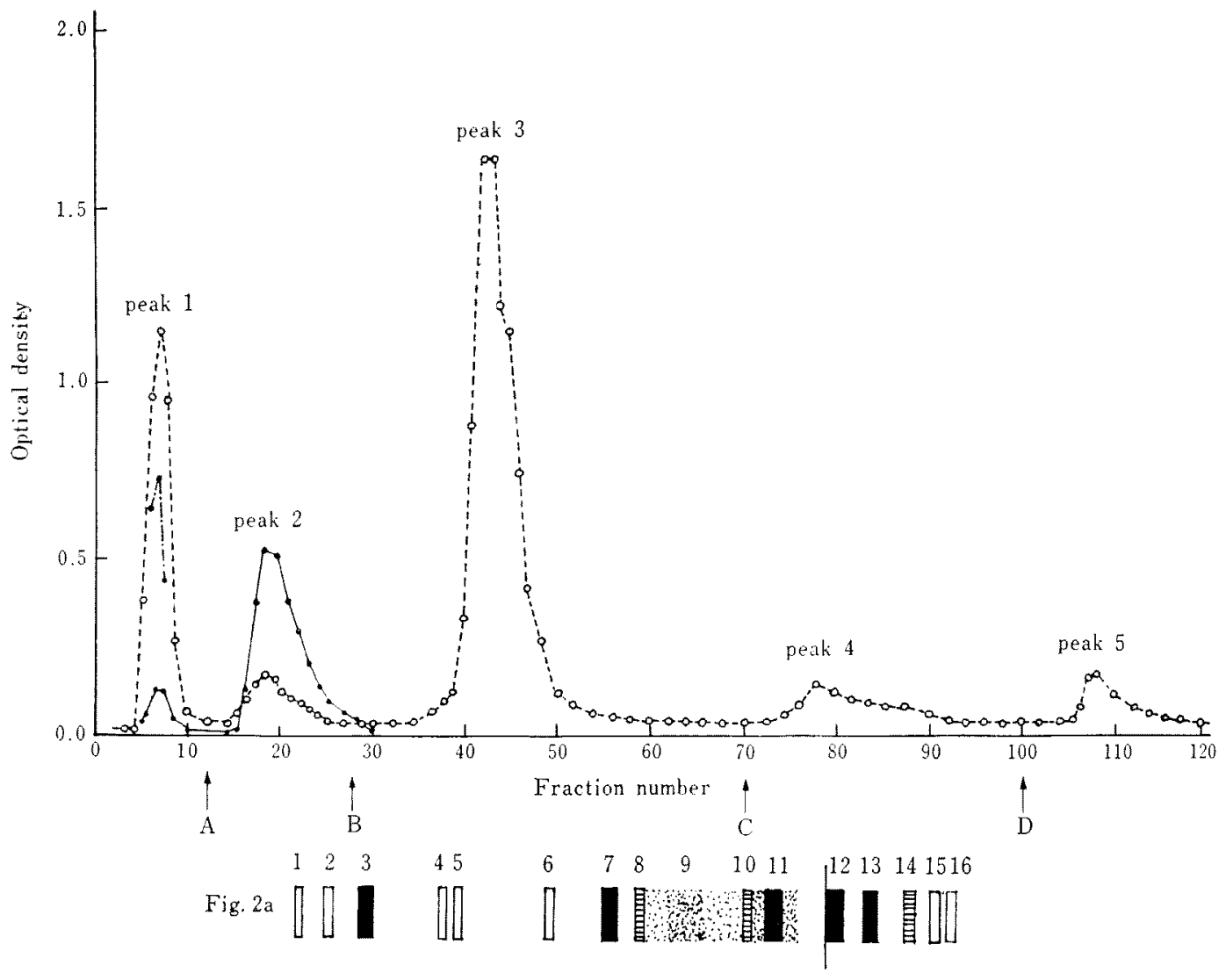

Fig. 2b

Fig. 2c

Arode

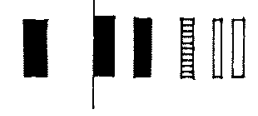

Original point Cathode

FIG. 2. CM-cellulose Chromatography of Sarcoplasmic Proteins.

The following buffers were used.

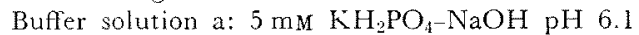
Buffer solution b: $5 \mathrm{mM} \mathrm{Na} \mathrm{HPO}_{4}$

Starting buffer; $a: b=10: 0$

After point $\mathrm{A} ; \mathrm{a}: \mathrm{b}=8: 2$ plus $\mathrm{KCl}$ to $20 \mathrm{mM}$

Optical density at $260 \mathrm{~m} \mu$ is not shown except a part of peak 1 , because abnormal absorption was not found.

Fig. 2a: Whole sarcoplasm as indicated in Fig. 1 a Fig. 2c: Starch gel electrophoresis of peak 3

Fig. 2 b: Starch gel electrophoresis of peak 1

Other peaks were not examined because of low yield of proteins. O--O O.D. at $280 \mathrm{~m} \mu,-\cdots$ O.D. at $260 \mathrm{~m} \mu$,
After point $\mathrm{B} ; \mathrm{a}: \mathrm{b}=5: 5$ plus $\mathrm{KCl}$ to $50 \mathrm{mM}$ After point $\mathrm{C} ; \mathrm{a}: \mathrm{b}=3: 7$ plus $\mathrm{KCl}$ to $100 \mathrm{mM}$ After point $\mathrm{D} ; \mathrm{a}: \mathrm{b}=0: 10$ plus $\mathrm{KCl}$ to $300 \mathrm{~mm}$ 


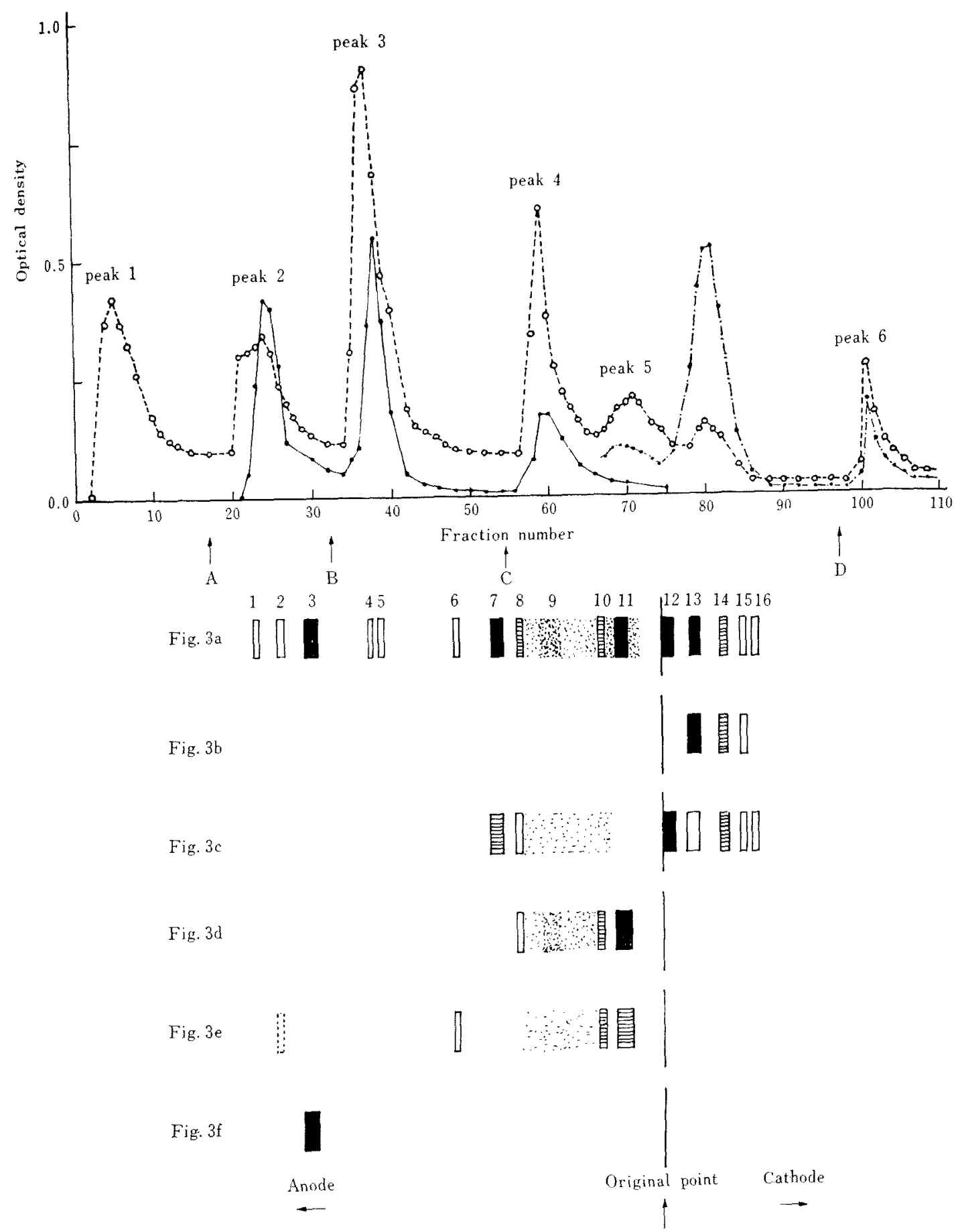

FIG. 3. Captions put into the bottom of the next page. 
Fig. $4 \mathrm{a}$

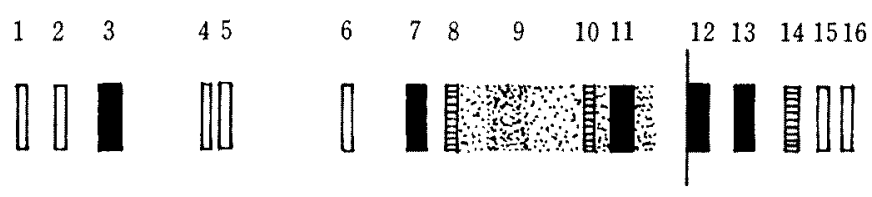

Fig. 4b
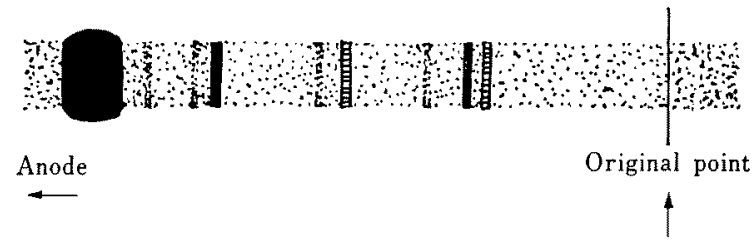

Cathode

FIG. 4. Starch Gel Electrophoresis of Rat Sarcoplasmic Proteins and Serum Proteins.

Fig. 4a: Sarcoplasmic proteins as indicated in Fig. 1 a.

Fig. 4 b: Serum Proteins.

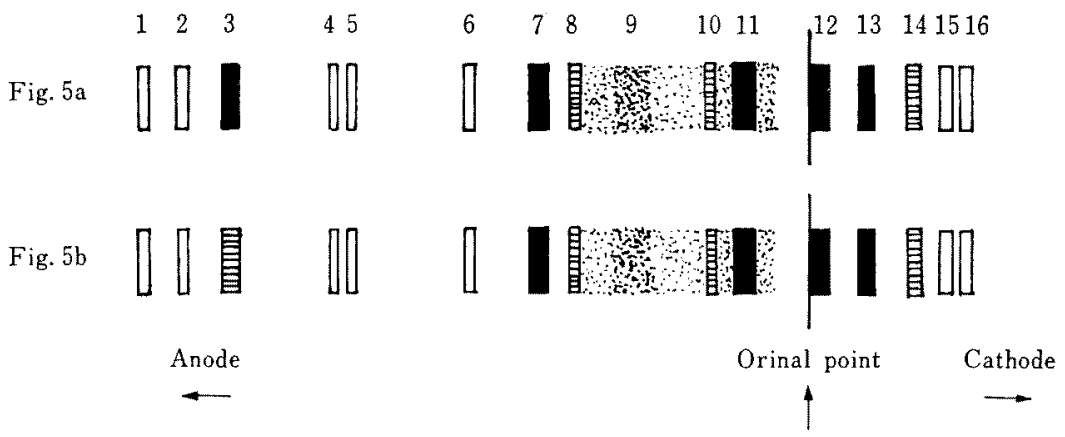

FIG. 5. Starch Gel Electrophoresis of Sarcoplasmic Proteins of Normal and Protein Depleted Rats.

Fig. 5a: Normal.

Fig. 5 b: Protein depleted.

Normal diet ${ }^{35}$ ) contained $65.6 \%$ corn starch, $20 \%$ whole egg protein, $50 \%$ soybean oil, $5 \%$ cellulose powder, $4 \%$ salt mixture, $0.3 \%$ vitamin mixture, and $0.1 \%$ choline chloride. Protein free diet contained $00^{\circ}$ whole egg protein and $85.60_{0}$ corn starch, and other components were the same as that of normal diet. Protein was depleted by giving the protein free diet for 16 or 32 days.

FIG. 3. DEAE-cellulose Chromatography of Sarcoplasmic Proteins.

Starting buffer: $40 \mathrm{~mm}$ glycine-NaOH pH 9.1 .

After point $\mathrm{A} ; \mathrm{KCl}$ was added to the buffer to $10 \mathrm{mM}$.

After point $\mathrm{B} ; \mathrm{KCl}$ was added to the buffer to $30 \mathrm{mM}$.

After point $\mathrm{C} ; \mathrm{KCl}$ was added to the buffer to $100 \mathrm{~mm}$.

After point $\mathrm{D} ; \mathrm{KCl}$ was added to the buffer to $200 \mathrm{mM}$.

Optical density at $260 \mathrm{~m} \mu$ is not shown except a part of the chromatogram, because abnormal absorption was not found.

Fig. 3a: Whole sarcoplasm as indicated in Fig. 1 a and Fig. 2 a.

Fig. 3 b: Starch gel electrophoresis of peak 1 .

Fig. $3 \mathrm{c}$ : Starch gel electrophoresis of peak 2.

Fig. 3d: Starch gel electrophoresis of peak 3.

Fig. 3 e: Starch gel electrophoresis of peak 4 and 5 .

Fig. 3f: Starch gel electrophoresis of peak 6 .

As for the symbols, see Fig. 2. 
procedure was used for CM-cellulose. Each cellulose was then equilibrated with the starting buffer. Sarcoplasmic proteins were dialyzed to the starting buffers and $30 \mathrm{ml}$ of dialyzates were applied to a column $(3 \times 13 \mathrm{~cm})$. In the case of CM-cellulose chromatography, dialysis of sarcoplasmic proteins against $10 \mathrm{mM}$ phosphate buffer brought about partial precipitation of proteins. The precipitate was removed by centrifugation and the supernatant was used as the samples of the chromatography.

One hundred and fifty drops of eluate each were collected and the optical densities at 280 $\mathrm{m} \mu, 260 \mathrm{~m} \mu$, and $410 \mathrm{~m} \mu$ (colored fractions) were measured. To the fractions of each peak were added solid ammonium sulfate until the saturation was attained. The precipitate was collected by centrifugation and dissolved in a small volume of $40 \mathrm{mM}$ glycine- $\mathrm{NaOH}(\mathrm{pH}$ 9.1) buffer in order to apply to the starch gel electrophoresis. DEAE-cellulose chromatography was performed according to Hartshorne and Perry. ${ }^{141}$

Starch gel electrophoresis. Vertical starch gel electrophoresis was done according to Smithies, ${ }^{26,27)}$ partially modified by Aoki. ${ }^{281}$ The size of gel tray was $6 \times 60 \times 260 \mathrm{~mm}$. One per cent of sodium chloride was used as the electrode solution and $110 \mathrm{mM}$ boric acid$\mathrm{NaOH}(\mathrm{pH} \mathrm{8.8)}$ as the bridge solution. Electrophoresis was performed for $16 \mathrm{hr}$ at the constant flow of $5 \mathrm{~mA}$. Proteins were stained with Amido Black $10 \mathrm{~B}$, lipid containing fractions with Oil Red $O$, and colored proteins with benzidine, according to Smithies. ${ }^{271}$

The electrophoretic pattern of whole sarcoplasm is shown in Fig. 1a. More than 16 zones were identified and numbered from anode to cathode. Large part of the proteins seems to be localized continuously between zone 7 and the original point. This part was designated as zone 9 tentatively. Since zone $3,11,12$ and 13 were also stained by Oil Red $O$, these zones seem to contain lipoproteins (Fig. $1 \mathrm{~b}$ ). Figure $1 \mathrm{c}$ shows the benzidine posi- tive zones. At least 3 zones were stained by this method, but they did not coincide with any zones of Amide Black $10 \mathrm{~B}$ staining. This result is in accordance with that of Laurent et $a^{29}{ }^{29}$ and probably with that of Formanek et $a l .{ }^{301}$ Figures $1 \mathrm{~d}, \mathrm{e}, \mathrm{f}$ and $\mathrm{g}$ show the electrophoretic patterns of fractions obtained by ammonium sulfate fractionation. Many zones were recovered in more than two fractions by this fractionation, except zone 7 and colored proteins which were almost exclusively recovered in the supernatant of $70 \% 6$ saturation.

Figure 2 shows the chromatographic pattern of sarcoplasmic proteins on CM-cellulose. The electrophoretic pattern of the fractions obtained by CM-cellulose chromatography is shown in Fig. $2 \mathrm{~b}$ and $\mathrm{c}$. More cathionic components than zone 8 were recovered in peak 3 and others were obtained in peak 1 . By this chromatography, colored proteins were recovered mainly in peak 2 . This method did not give good fractionation. One of the reasons for this result seems to be that CM-cellulose was used at $\mathrm{pH}$ 6.1. Below $\mathrm{pH}$ 6.0, many sarcoplasmic proteins precipitate, and, on the contrary, CM-cellulose does not function well above pH 6.0. In spite of these defects, CM-cellulose chromatography brought about clear-cut separation of zone 3 and 7 from other main zones.

Figure 3 shows the result of DEAE-cellulose chromatography, by which the sarcoplasmic proteins were fractionated into 6 main fractions. The electrophoretic patterns of the fractions are shown in Fig. $3 \mathrm{~b}, \mathrm{c}, \mathrm{d}$, e and $\mathrm{f}$. By this chromatography, components of sarcoplasmic proteins were eluted in order from cationic ones to anionic ones. Peak 6 contains zone 3 almost exclusively. The peak appeared between peak 5 and 6 showed stronger absorption at $260 \mathrm{~m} \mu$ than at $280 \mathrm{~m} \mu$, which suggests this fraction to be nucleic acid(s) or the related compound(s). Colored proteins were recovered mainly in the peaks 2 and 3 , but small portions were recovered also in the peak 4 . This result might suggest the heterogeneity of 
myoglobins ${ }^{30 \sim 32)}$ or coexistence of myoglobin, hemoglobin and their derivatives.

The problem whether or not the zones identified by starch gel electrophoresis are of muscle cell origin or serum origin, was examined. Figure 4 shows the result of this experiment. This result indicates that main zones of sarcoplasmic proteins are of muscle cell origin except zone 3. Zone 3, which presumably corresponds to myoalbumin described by Bates-Smith" and by Jacob, "' may or may not be serum protein origin as discussed by Gitlin et al. ${ }^{33,341}$ and by Hartshorne et al. ${ }^{1 \text { ( ) }}$ This problem remains to be elucidated.

Another problem whether or not protein depletion affects the electrophoretic pattern of sarcoplasmic proteins was further examined. The result is shown in Fig. 5 which suggests no effect of feeding protein-free diet on any zone except zone 3 . Zone 3 seems to decrease in the protein depleted animals. As serum albumin has been reported to decrease in protein depleted animals, ${ }^{36-381}$ this result should be studied further in relation with the above mentioned problem.

By applying ammonium sulfate fractionation, CM-cellulose chromatography, and DEAE-cellulose chromatography, sarcoplasmic proteins of rat skeletal muscle were fractionated into several fractions. The results are summarized in Fig. 6. From Fig. 6, it is suggested that some of the sarcoplasmic proteins were obtained as a single protein, as far as it was identified on the starch gel electrophoresis. For example, zone 3 can be obtained as a highly purified preparation by applying DEAE-cellulose chromatography, and zone 7 can be obtained by ammonium sulfate fractionation followed by CM-cellulose chromatography. Other zones can also be obtained as highly purified proparations by applying these techniques, even if they are not obtained as

\begin{tabular}{|c|c|c|c|c|c|c|c|c|c|c|c|c|c|c|c|c|c|}
\hline Zone No. & 1 & 2 & 3 & 4 & 5 & 6 & 7 & 8 & 9 & 10 & 11 & 12 & 13 & 14 & 15 & 16 & C.P." \\
\hline $\begin{array}{c}\text { Fraction } \\
\left(\mathrm{NH}_{4}\right)_{2} \mathrm{SO}_{4} \\
0-50 \%\end{array}$ & & & 自 & & & & & & & & 冒 & & & & $\square$ & $\square$ & \\
\hline $\begin{array}{c}\left(\mathrm{NH}_{4}\right)_{2} \mathrm{SO}_{4} \\
50-60^{\circ}\end{array}$ & & & 貣 & $\square$ & & & & 冒 & & 冒 & 貝 & 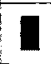 & $\square$ & 冒 & & & \\
\hline $\begin{array}{c}\left(\mathrm{NH}_{4}\right)_{2} \mathrm{SO}_{4} \\
60-70 \%\end{array}$ & & & 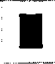 & & & D & & & 筇 & $\square$ & 7 & & 冒 & $\square$ & & & \\
\hline $\begin{array}{l}\left(\mathrm{NH}_{4}\right)_{2} \mathrm{SO}_{1} \\
70^{\circ},\end{array}$ & & & & & & & 口 & & & $\square$ & 冒 & & 冒 & & & & 冒 \\
\hline $\begin{array}{l}\mathrm{CMC} \\
\text { peak } 1\end{array}$ & & & $\mathbf{D}$ & & & $\square$ & & 貝 & & & & & & & & & \\
\hline $\begin{array}{l}\text { CMC } \\
\text { peak } 2\end{array}$ & & & & & & & & & & & & & & & & & 冒 \\
\hline $\begin{array}{c}\text { CMC } \\
\text { peak } 3\end{array}$ & & & & & & & & & & & 口 & & & 冒 & $\square$ & $\square$ & \\
\hline $\begin{array}{r}\text { DEAEC } \\
\text { peak } 1\end{array}$ & & & & & & & & & & & & & & 冒 & $\square$ & & \\
\hline $\begin{array}{r}\text { DEAEC } \\
\text { peak } 2\end{array}$ & & & & & & & & $\square$ & & & & $\pi$ & $\square$ & 冒 & $\square$ & $\square$ & 冒 \\
\hline $\begin{array}{r}\text { DEAEC } \\
\text { peak } 3 \\
\end{array}$ & & & & & & & & $\square$ & 涪 & 冒 & $\square$ & & & & & & 目 \\
\hline $\begin{array}{l}\text { DEAEC } \\
\text { peak } 4.5\end{array}$ & & & & & & D & & & & 目 & 見 & & & & & & $\square$ \\
\hline $\begin{array}{c}\text { DEAEC } \\
\text { peak } 6\end{array}$ & & & & & & & & & & & & & & & & & \\
\hline
\end{tabular}

FIG. 6. Summary of Fractionation of Sarcoplasmic Proteins.

As for symbols, see Fig. 1.

* Colored proteins 
a single protein. Further studies to obtain more purified preparations systematically are now under investigation and will be published later.

These studies may give methods for elucidating the metabolic heterogeneity of sarcoplasmic proteins or for studying the effects of hormones and drugs on synthesis and degradation of each sarcoplasmic protein.

\section{REFERENCES}

1) H. H. Weber and K. Meyer, Biochem. Z., 266, 137 (1933).

2) T. Baranowski, Hoppe Seyler's Z. Physiol Chem., 260, 43 (1939).

3) E. C. Bates-Smith, Biochem. J., 34, 1122 (1940).

4) J. J. C. Jacob, ibid., 41, 83 (1947).

j) A. Distèche, Biochim. Biophys. Acta, 2, 265 (1948).

6) J. J. Connell, Biochem. J., 55, 378 (1953).

7) B. A. Askonas, ibid., 48, 42 (1952).

8) J. J. Connell, ibid., 69, 5 (1958).

9) B. P. Hughes, Biochem. Biophys. Res. Comm., 1, 194 (1959).

10) L. Marcand, Compt. Rend. Soc. Biol., 154, 1209 (1960).

11) B. P. Hughes, Clin. Chim. Acta, 6, 794 (1961).

12) R. Laurent, J. C. Dreyfus and G. Schapira, Bull. Soc. Chem. Biol., 43, 423 (1961).

13) B. G. Giles, J. Sci. Food Agr., 13, 264 (1962).

14) D. J. Hartshorne and S. V. Perry, Biochem. J., 85, $171(1962)$.

15) H. Tsuyuki, E. Roberts and R. E. A. Gadd, Can. J. Biochem. Physiol., 40, 919 (1962).

16) H. Tsuyuki, E. Roberts and R. E. A. Gadd, ibid., 40,929 (1962).

17) N. R. Chagovets, Vopr. Med. Khim., 8, 599 (1962).

18) J. M. Neelin, Can. J. Biochem. Physiol., 41, 369 (1963).
19) R. K. Scopes, Biochem. J,, 91, 201 (1964).

20) M. Fujimaki and F. E. Deatherage, J. Food Sci., 29, 316 (1964).

21) J. H. Rampton, A. F. Anglemier and M. W. Montogomery, ibid., 30, 636 (1965).

22) R. K. Scopes, Biochem. J., 107, 139 (1968).

23) G. B. Thompson, W. D. Davidson, M. W. Montgomery and A. F. Anglemier, J. Food Sci, 33, 68 (1968).

24) L. L. Borchert, W. D. Powrie and E. J. Briskey, ibid., 34, 148 (1969).

25) M. Yamaguchi and M. Kandatsu, unpublished works.

26) O. Smithies, Biochem. J., 61, 629 (1955).

27) O. Smithies, Adv. Prot. Chem., 14, 61 (1959).

28) K. Aoki, Protein, Nucleic Acid and Enzyme, 7, 338 (1962).

29) R. Laurent, J. D. Dreyfus and G. Schapira, Bull. Soc. Chim. Biol., 43, $\$ 15$ (1961).

30) K. Formanek, R. Kaschmitz and J. Patsch, Hoppe Zeyler's Z. Physiol. Chem., 348, I352 (1967).

31) G. T. Perkoff, R. L. Hill, D. M. Brown and F. H. Tyler, J. Biol. Chem., 237, 2820 (1962).

32) A. Akeson and H. Teorell, Arch. Biochem. Biophys., 91, $319(1960)$.

33) D. Gitlin and C. A. Janewary, Science, 120, 461 (1954).

34) D. Gitlin, D. Nakasato and W. R. Richardson, J. Clin. Invest., 34, 935 (1955).

35) M. Yamaguchi and M. Kandatsu, Agr. Biol. Chem., 31, 1372 (1967).

36) C. H. Barrows, Jr., and B. F. Chow, in "Protein and Amino Acid Nutrition," ed. by A. A. Albanese, Academic Press, New York, 1959, pp. $119 \sim 130$.

37) R. W. Wannemacher, Jr, , T. J. Russll and J. B. Allison, J. Nutrition, 80, 63 (1963).

38) J. B. .llison, in "Mammalian Protein Metabolism," Vol. 2, ed. by H. N. Munro and J. B. Allison, Academic Press, New York, 1964, pp. $74 \sim 75$. 